\title{
ЗБАГАЧЕННЯ ФОРТЕПІАННОГО РЕПЕРТУАРУ МАЙБУТНІХ ВІЙСЬКОВИХ ДИРИГЕНТІВ ЯК УДОСКОНАЛЕННЯ ЇХНЬОЇ ПРОФЕСІЙНОЇ МАЙСТЕРНОСТІ
}

Відповідальність вищих військових навчальних закладів (ВВНЗ) за стан професійної підготовки майбутніх спеціалістів в умовах гібридної агресії Росії зростає з кожним днем. Сучасний військовий диригент, виступаючи в якості офіцера-керівника, начальника, творчого наставника, досвідченого музиканта-виконавця, повинен швидко реагувати на виклики часу і творчо підходити до розв'язання поставлених перед ним завдань. Отже, вдосконалення професійної майстерності майбутніх військових диригентів кафедри музичного мистецтва Національної академії сухопутних військ (НАСВ) має відбуватися вже в період їх навчання.

У професійній педагогіці, сучасній музикознавчій науці останнім часом надзвичайна увага приділяється питанням удосконалення професійної майстерності. «Майстерність» тлумачиться як: «1. Умілість, вправність. 2. Висока якість виконаної роботи, твору тощо; досконалість» [1, с. 504]. Музичне мистецтво розглядає майстерність як невід'ємну складову музично-виконавської діяльності.

У вітчизняній музичній педагогіці поняття «музична виконавська майстерність» уперше сформульовано видатним музикантом, педагогом, професором М. Давидовим: «Виконавська майстерність є вільним володінням інструментом і собою, емоційно яскраве, артистичне, співтворче, технічно досконале втілення музичного твору в реальному звучанні» [2].

Майстерність майбутнього військового диригента вдосконалюється у процесі професійної підготовки на кафедрі музичного мистецтва $\mathrm{HACB}$, зокрема на заняттях із фортепіано. «Володіти грою на фортепіано в тій чи іншій мірі повинен кожен освічений музикант. У процесі навчання вивчення музичної літератури, гармонії, читки партитур без фортепіано просто неможливе» [4, с. 5].

У музичній педагогіці безліч праць вітчизняних і зарубіжних педагогів-музикантів, таких як О. Алексєєв, Л. Баренбойм, Т. Беркман, В. Бєлікова, О. Бодіна, О. Бурська, Т. Воробкевич, О. Гольденвейзер, Й. Гофман, М. Давидов, Б. Землянський, Г. Коган, Н. Любомудрова,

(C) Руслана Ваврик, 2019 
В. Макаров, К. Мартінсон, Б. Міліч, В. Москаленко, Я. Мільштейн, Г. Нейгауз, Г. Прокоф'єв, Р. Савицький, С. Савшинський, Т. Смірнова, А. Стоянов, С. Тимакін, С. Фейнберг, Г. Ципін, О. Щапов, Б. Яворський та інші, які розкривають основи початкового навчання, розвитку музично-виконавського мислення, оволодіння виконавськотехнічними навичками, теорії музичного виконавства. Проте природа виконавського мистецтва, його традиції та особливості функціонування в сучасному музичному просторі зумовлюють змінність поглядів музикантів різних поколінь на виконавську діяльність і наповнюють новим змістом процес удосконалення професійної майстерності.

У Львівській національній музичній академії імені М. В. Лисенка впроваджено курс загального «Фортепіано» для студентів-непіаністів із дворічним терміном навчання і спеціалізованого «Фортепіано» (вивчають теоретики, композитори і диригенти) - три роки навчання. Упродовж навчально-виховного процесу дидактичний репертуар студентів охоплює велику градацію творів: етюди, п'єси, твори великої форми, поліфонічні, акомпанемент, ансамблі та інші, що вимагає значних затрат часу для вивчення такого обсягу музичного матеріалу.

Особливість підготовки майбутніх військових диригентів із даного предмета запрограмована на більш короткий термін (у зв'язку з великим обсягом військових дисциплін), охоплює всього півтори роки навчання та вимагає від курсантів застосування неабияких зусиль, щоб опанувати гру на фортепіано в такий стислий термін відповідно до вимог програми 3 навчальної дисципліни. Враховуючи те, що на кафедру музичного мистецтва НАСВ поступають курсанти з різних регіонів України, і у них, відповідно, різні професійні рівні, перед викладачем постає питання диференціації та індивідуалізації навчання кожного курсанта, зорієнтованого на його музичний розвиток. Також необхідно відзначити, що підвищення професійних вимог до майбутніх військових диригентів і півторарічний термін викладання предмета при повному обсязі практичного вивчення музичних творів згідно робочого навчального плану з навчальної дисципліни «Фортепіано» вимагає від викладача створення відповідних умов на уроці для засвоєння навчального матеріалу, впровадження інновацій, застосування методики викладання предмета 3 урахуванням музичних здібностей кожного курсанта задля подальшого зростання його професійного рівня.

Викладачеві необхідно грамотно, компактно і ретельно підібрати дидактичний музичний матеріал з орієнтацією на майбутню професійно-виконавську діяльність курсантів, збагатити їх репертуар тво- 
рами сучасних композиторів. Головною метою при викладанні дисципліни є досягнення здатності курсанта самостійно виконувати музичний твір на високохудожньому професійному рівні та майстерно донести до слухача його образно-емоційний зміст.

«Урок з фортепіано, будучи комплексним, синтезує кілька видів музичної діяльності: виконавський (спів, гра на фортепіано й ілюстрування на інших інструментах); аналітичний - аналіз творів, що виконуються, їх структури, форми, образного змісту, технічних прийомів, аплікатури; практико-технологічний (пов'язаний із процесом виконання дуетів або акомпанементом на фортепіано студентам інших спеціальностей); методичний - оскільки на уроці студенти свідомо сприймають методичні настанови, рекомендації педагога» [3, с. 84-35].

Як свідчать матеріали наукових публікацій, методичних порад, педагогічних рекомендацій, зусилля багатьох сучасних викладачів спрямовані на пошук нових і вдосконалення відомих методів оволодіння грою на фортепіано, шляхів збагачення навчально-педагогічного репертуару для студентів творами українських і зарубіжних композиторів різних стилів, жанрів і форм (Р. Ваврик, М. Герега, О. Гнатишин, Н. Дика, 3. Жмуркевич, Л. Каравацька, О. Катрич, I. Кукоба, Н. Лукашенко, Т. Омельченко, Р. Панчук та ін.).

Метою даної публікації є обгрунтування необхідності збагачення фортепіанного репертуару для майбутніх військових диригентів, висвітлення основних проблем, із якими стикається музикант, коли вивчає музичний твір, і надання відповідних методичних рекомендацій щодо їх подолання.

Вдосконалення професійної майстерності майбутнього військового диригента відбувається поступово під дією доцільно побудованої методики, яка дозволяє забезпечити необхідний результат щодо підвищення рівня його фахової спроможності. У процесі навчання формується і розвивається індивідуально-виконавський стиль особистості, педагог проектує і прогнозує творчі досягнення кожного курсанта, складає індивідуальний план навчання, стимулює його прагнення досягнути найвищого рівня професійної майстерності, враховуючи домінуючий тип його темпераменту. Власне тим і пояснюється прихильність курсантів до тих чи інших фортепіанних творів, що має враховувати викладач при виборі творів із репертуару на різних етапах навчання.

Крім того, рівень музичних здібностей курсанта зумовлює відповідну градацію репертуарного списку фортепіанних творів, які він опрацьовує за принципом: від простого до складного за весь період навчання. На заняттях із навчальної дисципліни «Фортепіано» курса- 
нти вивчають твори різних стилів, жанрів і форм. Репертуарна амплітуда має постійно доповнюватися сучасними творами українських $\mathrm{i}$ зарубіжних авторів, закладаючи інтелектуальний потенціал творчої особистості та вдосконалюючи смаки молодого виконавця.

До жанру фортепіанної мініатюри зверталося багато українських композиторів, які створили високохудожні твори дидактичного спрямування щодо вдосконалення професіоналізму музикантів: В. Барвінський, В. Косенко, Б. Кудрик, М. Лисенко, 3. Лисько, Б. Лятошинський, Н. Нижанківський, Л. Ревуцький, А. Рудницький, Я. Степовий та ін.

Сучасні українські композитори В. Антонюк, О. Білаш, Я. Бобалік, Е. Брилін, Ю. Діброва, Ю. Корженко, М. Ластовецький, Р. Панчук, О. Серова, В. Сильвестров, М. Скорик, Б. Фільц, О. Шимко, М. Шоренков та інші в жанрі фортепіанної мініатюри майстерно наповнюють невеликий за обсягом художній твір значним змістом, не порушуючи вимог одночастинної, дво- або тричастинної форми.

Досвід викладацької роботи завжди спонукає до творчого пошуку і написання творів для фортепіано, які б сподобалися курсантам, мотивували ïx до подолання технічно-виконавських труднощів у п'єсах і збагатили уявно-тембральне, художньо наповнене емоційне забарвлення музики. Так у списку пропонованих творів до музикування з'явилися дві п'єси для фортепіано у жанрі фортепіанної мініатюри і два етюди (автор - Р. Ваврик).

При опрацюванні фортепіанний твір вимагає здійснення ретельного аналізу авторського тексту, зокрема ритму, гармонії, особливостей фактури, усвідомлення функцій голосів, їх взаємодії, динамічного плану, загального фразування, та потребує адекватного відтворення нотного запису під час гри на інструменті. Для розкриття художнього змісту п’єс, різних за характером і жанрами, виконавцю необхідно вдосконалювати свою майстерність оволодіння прийомами фортепіанної техніки та всіх засобів музичної виразності.

Розглянемо окремі фортепіанні мініатюри, адресовані курсантам-диригентам, а також студентам і учням музичних навчальних закладів. Усі композиції створені для засвоєння певних технічних фортепіанних прийомів, мають програмні назви, прості за формою побудови, логічно структуровані. Їх умовно можна класифікувати як п’єси-настрої, етюди.

Наприклад, перша п’єса «Радість» висвітлює яскравий образ, передає неповторність магії потоку фортепіанного звучання, розкриває чуттєву градацію настроєвих змін. Фортепіанний твір лаконічний у висловлюванні, фактура розподілена на мелодичний і акомпануючий 
плани. Характер музики надзвичайно рухливий, звуковий матеріал вимагає відповідного інтонування, з елементами прихованої поліфонії та своєрідного динамічного забарвлення. Зазначимо, що у творі всього 32 такти. Форма побудови - проста тричастинна (А В А). Автор якомога доступніше намагалася донести до сучасного слухача відтворення світлого почуття радості, щастя... (рис. 1).

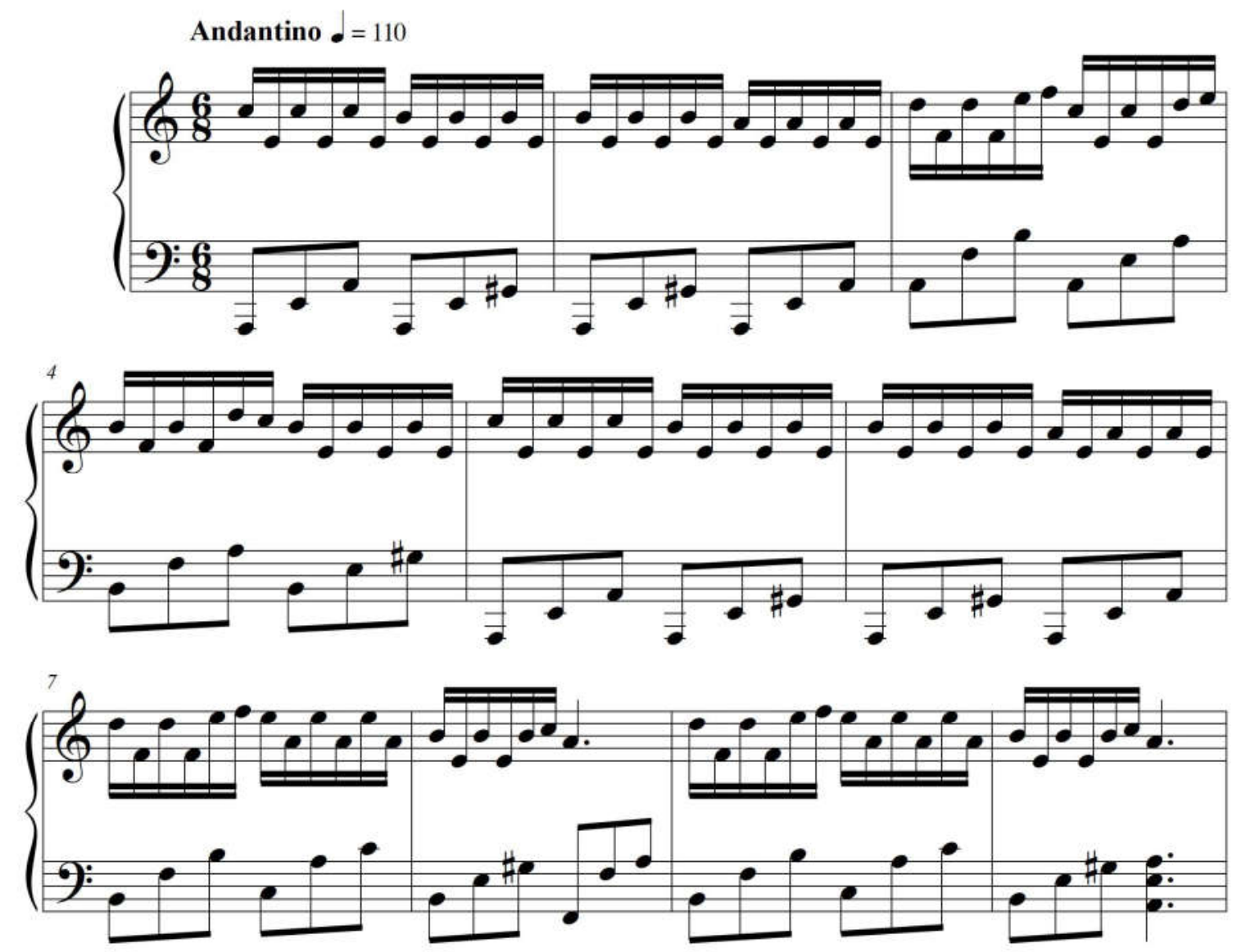

Рисунок 1 - Фрагмент п’єси «Радість»

У п'єсі особливе значення надається ритму, який передає рух, викликаючи стан емоційно-радісного хвилювання на короткому часовому просторі звучання фортепіанного твору. Технічно-віртуозна сторона виконання даного твору вимагає вправності, «бісерної гри», точного регістрового розподілу положення рук, майстерності володіння туше. Завдяки продуманій педалізації можна досягнути враження звукового об'єму та просторовості.

Наступний фортепіанний твір також має програмну назву - «Забавка». Він невеликий за обсягом (45 тактів). Висвітлення різнобарвної гами відчуттів відкриває широкі можливості для вияву творчої фантазії виконавця і використання можливості звучання фортепіано у втіленні образу (рис. 2). 

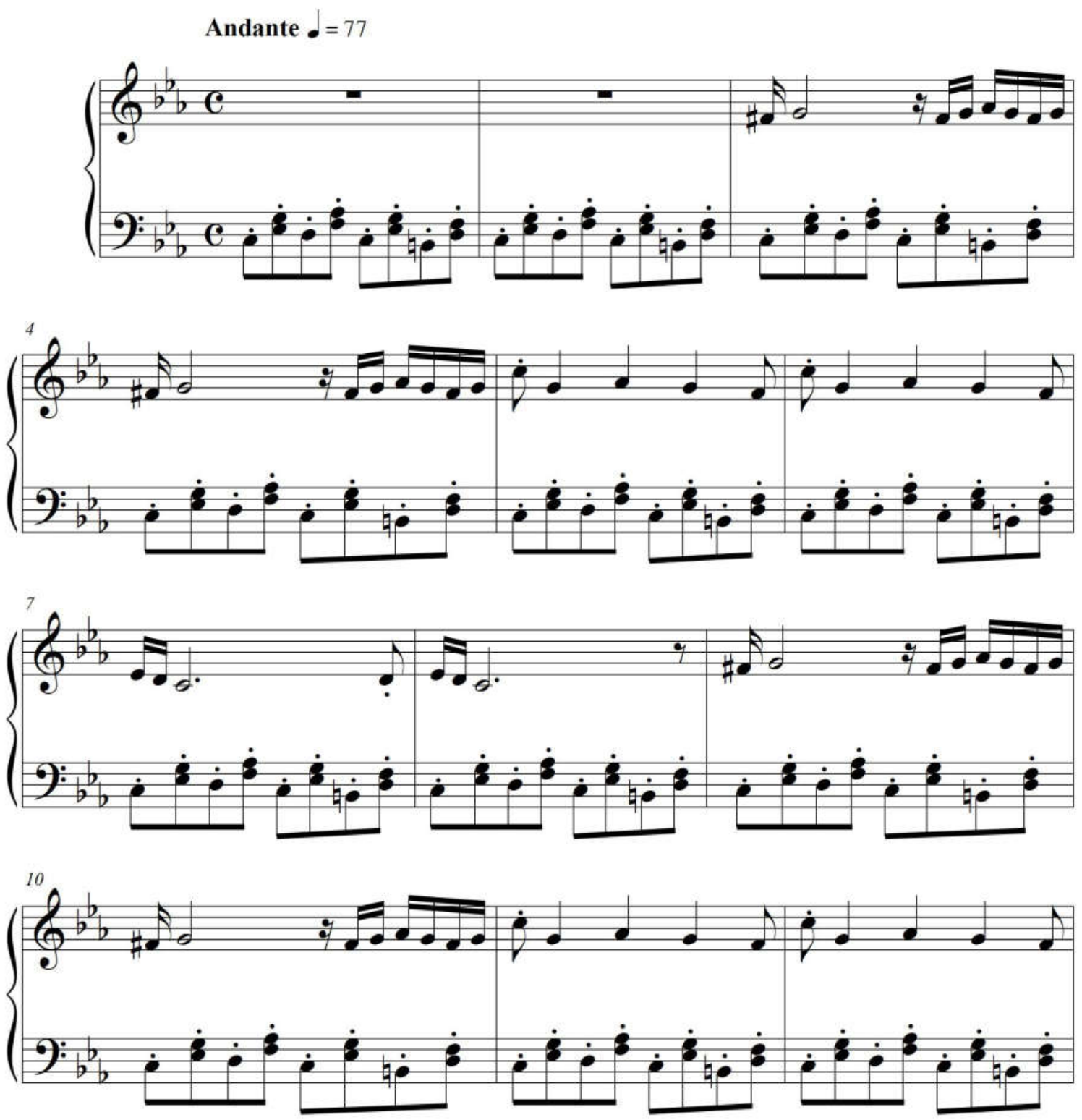

Рисунок 2 - Фрагмент п’єси «Забавка»

П'єса має просту, інтонаційно насичену прозору фактуру та вимагає від виконавця ретельного прочитання авторського тексту, відпрацювання різних штрихів, чіткості артикуляції в басовому викладенні та відповідного відтворення на інструменті. Використання педалі продиктоване характером музики. У композиції переважає раціонально-конструктивне начало щодо повторення тематичного матеріалу, квадратність, симетрія та ін. За бажанням курсант як майбутній диригент може зробити інструментальний переклад твору для складу військового духового оркестру.

Два етюди написані в ля-мінорі, форма побудови - проста тричастинна форма (А В А). Етюд № 1 - вельми піаністичний, наспівна мелодія звучить на тлі барвистого гармонічного супроводу. Твір вимагає від виконавця дотримання чітко продуманих аплікатурних позицій, не міс- 
тить явних технічних труднощів, хоча просторова відстань між руками створює певні піаністичні незручності, подолання яких потребує від піаніста відповідного рівня виконавської майстерності (рис. 3).
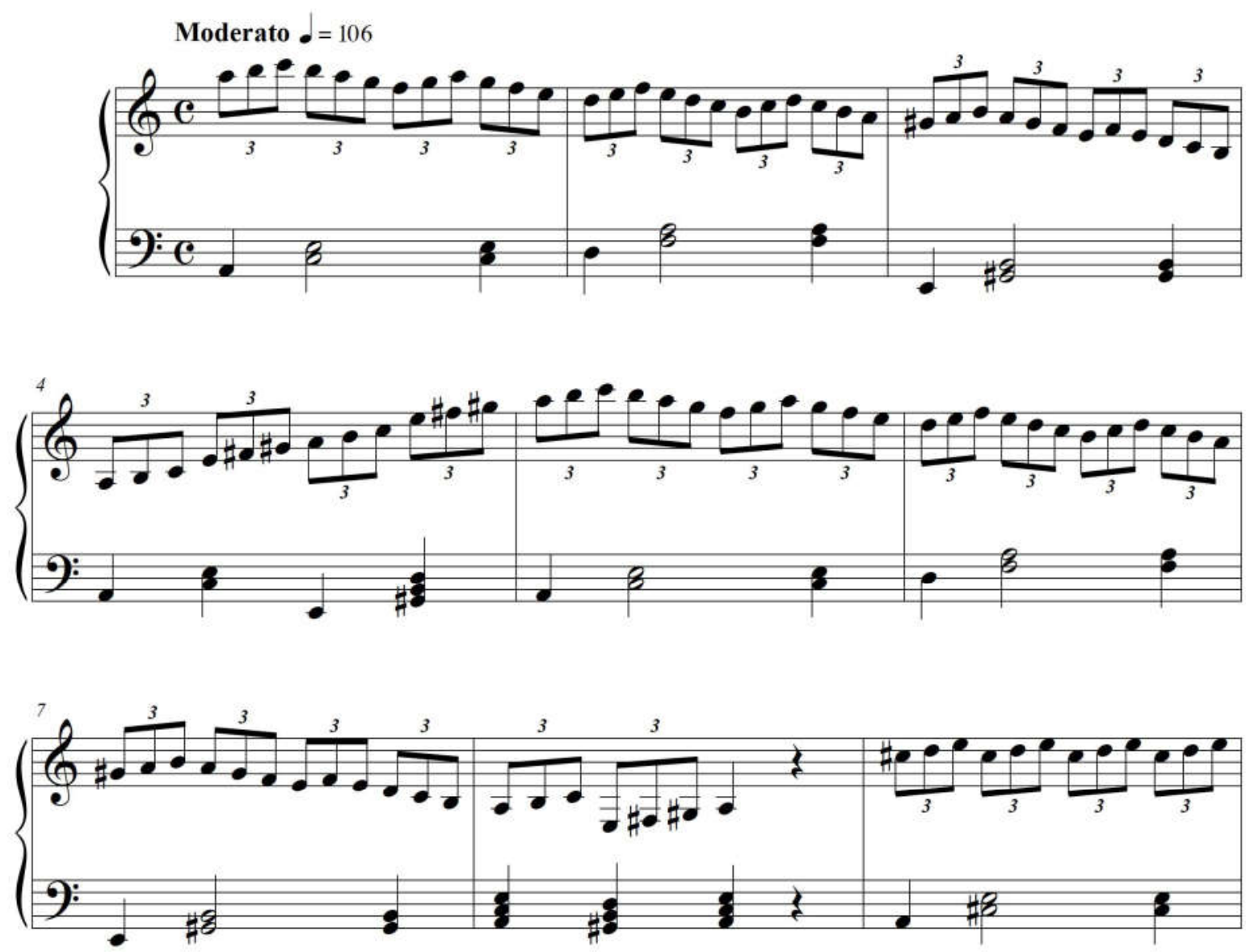

Рисунок 3 - Фрагмент етюда № 1

Зазначимо, що пропонований твір віддзеркалює комплекс таких стильових рис: лаконізм і простота форми, прозорість і ясність фортепіанної фактури, конструктивна логіка і довершеність цілого.

Етюд № 2 вирішує технічне завдання щодо розвитку фортепіанної вправності лівої руки. Роботу над технічними складностями у творі слід розпочинати з аналізу фактурних і піаністичних особливостей викладу та пошуку відповідних виконавських прийомів. Одним із найефективніших методів роботи над технічно складними місцями у п’єсі $є$ «виокремлення труднощів», що передбачає їх подолання за рахунок посиленої роботи окремими і двома руками різними способами, змінними штрихами, в різноманітних темпових амплітудах над більш важкими фрагментами нотного тексту. Мелодія твору кантиленного характеру, написана в інтервальному викладі та вимагає від виконавця наспівності звучання через пошук відповідних аплікатурних позицій і прийомів звуковидобування (рuс. 4). 

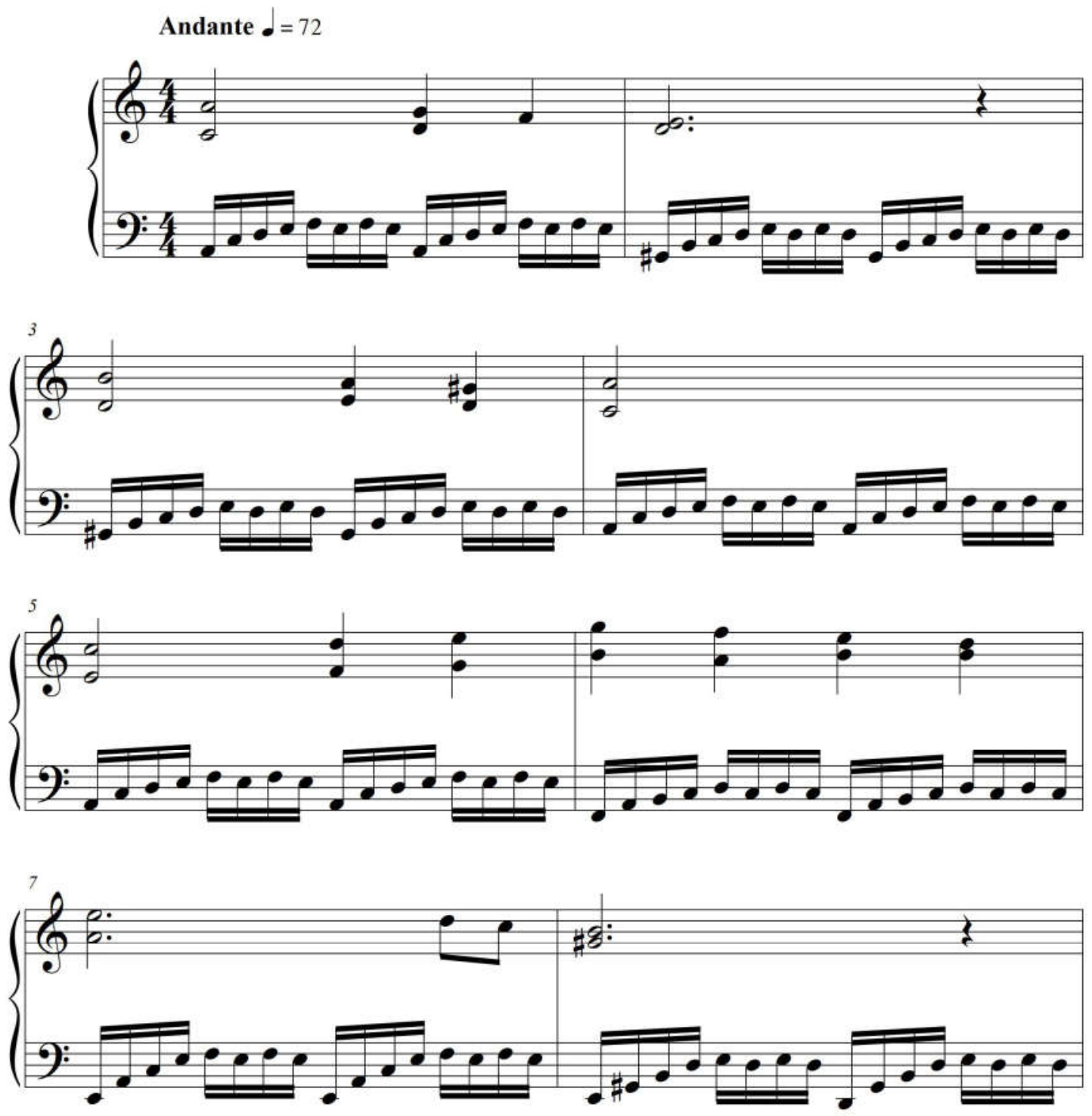

Рисунок 4 - Фрагмент етюда № 2

Відтак, запропоновані фортепіанні твори є прекрасним дидактичним матеріалом, який може збагатити навчально-педагогічний репертуар курсантів-диригентів, учнів і студентів мистецьких закладів музичного спрямування.

У Львівській національній музичній академії імені М. В. Лисенка на кафедрі загального і спеціалізованого фортепіано студенти завжди активно брали участь у кафедральних, тематичних концертах. Будучи автором музики і тексту пісень на різноманітну тематику, а також пісень для дітей, які неодноразово звучали на конкурсах, фестивалях, радіо і телебаченні (ТзОВ «Ліда» випустила компакт-диски: «Різдво на Галичині» Ч. 2 та збірку дитячих пісень «Сонячний зайчик», до яких увійшли написані нами пісні), у процесі творчого пошуку ми 
написали твір для голосу з фортепіано «Квітка і душа» в жанрі романсу на слова поетеси і композитора Мар'яни Лиховид (рuс. 5).

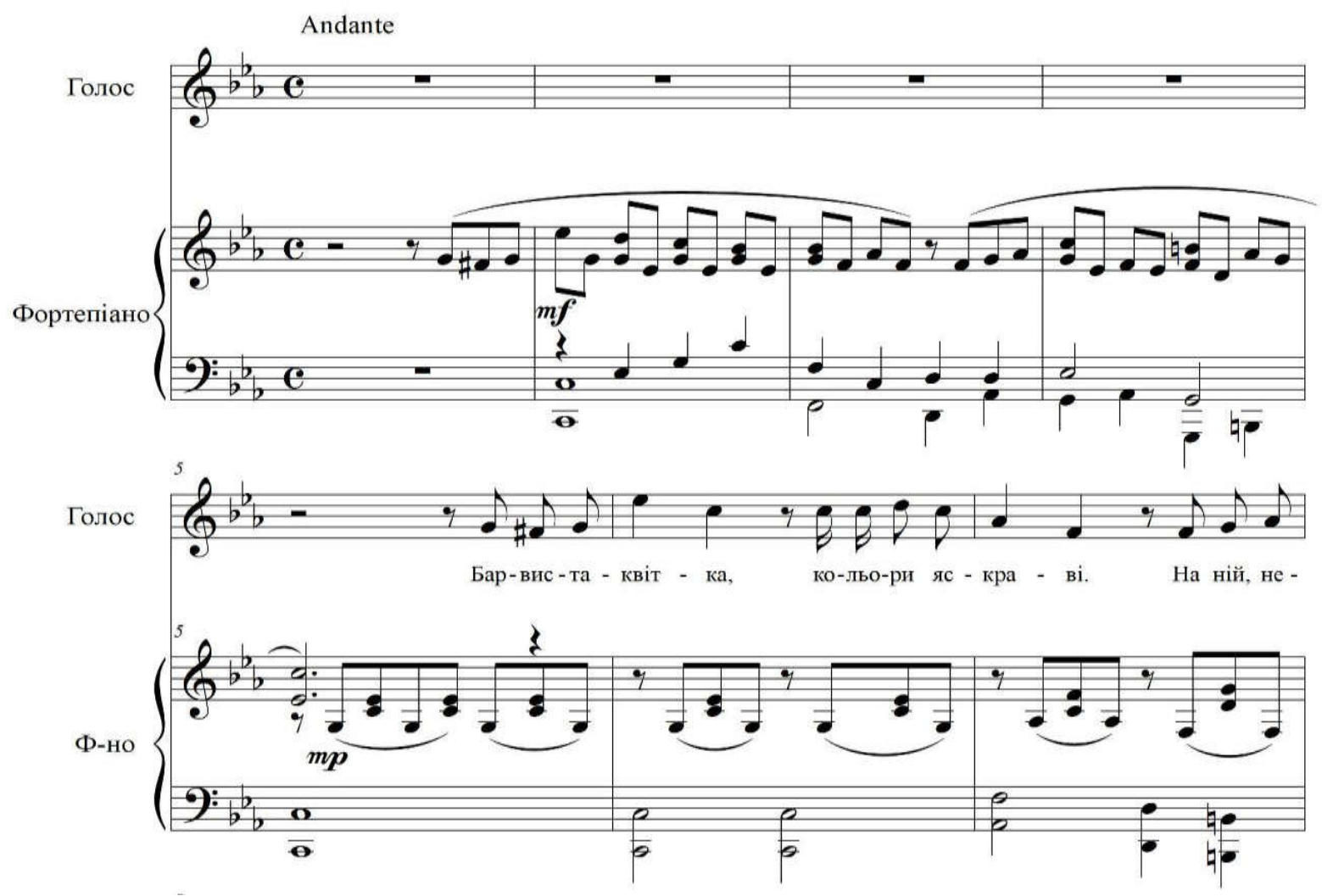

Рисунок 5 - Фрагмент твору «Квітка і душа»

Твір уперше прозвучав у виконанні студентки 1 курсу вокального факультету Андріяни Сенів на концерті «Музичний альманах» кафедри загального та спеціалізованого фортепіано в Малому залі Львівської національної музичної академії імені М. В. Лисенка 18 листопада 2010 р. Виступ був тепло сприйнятий слухачами, а також викладачами, присутніми на концерті.

Таким чином, на основі власного багаторічного досвіду варто відзначити, що під час вивчення музичних творів у жанрі фортепіанної мініатюри курсант здійснює теоретичний аналіз щодо тональності, розміру, будови форми, викладу фактури, ритмічних формул, аплікатури, темпу, динаміки, визначення кульмінаційного моменту твору, авторських ремарок, планує поетапність роботи, опрацьовує твір на інструменті, визначає методи подолання існуючих технічних труднощів, аналізує гру, звертаючи увагу на звуковий результат своїх практичних дій, усуває різноманітні недоліки, набуває та поглиблює свої теоретичні та практичні знання, вдосконалює виконавські вміння і навички.

Музично-виконавський досвід роботи над п'єсою спонукає до використання прийомів асоціативного мислення, багатозначного світо- 
сприйняття. У процесі музикування курсант виступає як виконавець і співавтор твору та несе повну відповідальність за реалізацію його художнього задуму. Зрештою, це допоможе його професійному становленню в майбутньому.

Отже, підсумовуючи вище сказане, зазначимо, що збагачення фортепіанного репертуару майбутніх військових диригентів є одним із чинників удосконалення їх професійної майстерності, продиктованого сучасними викликами. Професіоналізм військового колективу і диригента визначається рівнем художньо-виконавської майстерності музики різних епох, стилів і жанрів. Відповідно фортепіанний репертуар має охоплювати найрізноманітніші музичні твори українських і зарубіжних композиторів, йому повинна бути властива висока художня змістовність, відповідна педагогічна доцільність з урахуванням загального музичного розвитку й індивідуальних особливостей, нахилів, бажань кожного виконавця. Вдале вирішення підбору навчального репертуару впливає на вдосконалення професійної майстерності майбутніх військових диригентів і сприяє творчому зростанню їх потенціалу. Перспективи подальших розвідок у цьому напрямі спонукають до пошуку нових форм, способів, а також умов удосконалення професійної майстерності молодих музикантів.

\section{Лimepamypa:}

1. Великий тлумачний словник сучасної української мови / Уклад. і голов. ред. В. Т. Бусел. К. : Ірпінь: ВТФ «Перун», 2004. 1440 с.

2. Давыдов Н. А. Теоретические основы формирования исполнительского мастерства баяниста : автореф. дисс. ... д-ра искусствоведения : 17.00.02. К., 1990. 29 с.

3. Дубровська Г. Методичні розробки з практики фортепіанно-ансамблевої гри у класі загального та спеціалізованого фортепіано, як засіб гармонійного розвитку студентів. Загальне та спеціалізоване фортепіано у мистецькому просторі $\mathrm{V}_{\kappa-}$ раїни : зб. статей. ЛНМА ім. М. В. Лисенка / редкол. : І. Пилатюк (гол. ред.) та ін.; ред.-упоряд. 3. Жмуркевич, М. Герега. Львів : СПОЛОМ, 2012. С. 80-87.

4. Старко О. О. Деякі особливості курсу загального фортепіано та його роль у підвищенні якості професійної майстерності майбутнього спеціаліста. Суть і функиії загального і спеціалізованого фортепіано в процесі комунікаиії предметного дискурсу : матеріали ювілейної конференції з нагоди 55-річчя заснування кафедри, 6 грудня 2016 р. / Упор. О. Гнатишин. Львів : ЛНМА ім. М. Лисенка, 2016. С. 5-6.

\section{References (transliterated and translated):}

1. Velykyi tlumachnyi slovnyk suchasnoi ukrainskoi movy (Great explanatory dictionary of contemporary Ukrainian language) / Compiler and editor-in-chief V. T. Busel. Kyiv : Irpen: VTF «Perun», 2004. 1440 p. (in Ukrainian).

2. Davydov N. A. Teoreticheskie osnovyi formirovaniya ispolnitelskogo masterstva bayanista : avtoref. diss. ... d-ra iskusstvovedeniya (Theoretical bases of forming 
accordionist's performing skills : Author's abstract of thesis... doctor of art history : 17.00.02). Kyiv, 1990. 29 p. (in Russian).

3. Dubrovska H. Metodychni rozrobky z praktyky fortepianno-ansamblevoi hry u klasi zahalnoho ta spetsializovanoho fortepiano, yak zasib harmoniinoho rozvytku studentiv (Teaching manual on the practice of piano-ensemble play in the class of general and specialized piano as a means of students' harmonious development). Zahalne ta spetsializovane fortepiano u mystetskomu prostori Ukrainy : zb. statei. LNMA im. M. V. Lysenka (General and specialized piano in the artistic space of Ukraine : Collected works. LNMA named after M. V. Lysenko / Ed. by I. Pilatyuk (head) et. al.; compilers: Z Zhmurkevich, M. Hereha. Lviv: SPOLOM, 2012. P. 80-87. (in Ukrainian).

4. Starko O. O. Deiaki osoblyvosti kursu zahalnoho fortepiano ta yoho rol u pidvyshchenni yakosti profesiinoi maisternosti maibutnoho spetsialista (Some peculiarities of the course of the general piano and its role in improving the quality of professional skills of the future specialist). Sut i funktsii zahalnoho $i$ spetsializovanoho fortepiano v protsesi komunikatsii predmetnoho dyskursu : materialy yuvileinoi konferentsii (Essence and functions of general and specialized piano in the process of communication of subject discourse : Proceedings of the conference on the occasion of the 55th anniversary of the department founding, December 6, 2016) / Compiler O. Gnatyshyn. Lviv : LNMA named after M. Lysenko, 2016. P. 5-6. (in Ukrainian).

Стаття надійшла до редакції 02.12.2018

Р. Ваврик

\section{Збагачення фортепіанного репертуару майбутніх військових} диригентів як удосконалення їхньої професійної майстерності

У контексті вдосконалення професійної майстерності майбутніх військових диригентів перед викладачами загальних і спеціалізованих музичних дисциплін кафедри музичного мистецтва Національної академії сухопутних військ постає завдання пошуку різних шляхів реалізації цієї мети. Один із них - збагачення навчально-педагогічного репертуару 3 навчальної дисципліни «Фортепіано» музичними творами сучасних авторів. Головною метою при викладанні дисципліни є досягнення здатності курсантом самостійно виконувати музичний твір на високохудожньому професійному рівні та майстерно донести до слухача його образно-емоційний зміст. Підвищення музично-виконавських вимог до майбутніх військових диригентів, стислі часові обмеження при повному обсязі практичного вивчення музичних творів згідно робочого навчального плану 3 навчальної дисципліни «Фортепіано» вимагає від викладача створення відповідних умов на уроці для засвоєння навчального матеріалу, впровадження інновацій, застосування методики викладання предмета з урахуванням музичних здібностей кожного учня задля подальшого зростання його професійного рівня. У процесі викладання дисципліни специфіка навчально-педагогічного репертуару з фортепіано охоплює 
такі твори, як етюди, поліфонічні твори, п’єси малих форм, твори великої форми, ансамблеві твори, акомпанемент та ін. Фортепіанний репертуар має охоплювати найрізноманітніші музичні твори українських і зарубіжних композиторів, йому повинна бути властива висока художня змістовність, відповідна педагогічна доцільність з урахуванням загального музичного розвитку й індивідуальних особливостей кожного курсанта. У даній публікації вперше представлено результати творчого пошуку щодо збагачення навчально-педагогічного фортепіанного репертуару майбутніх військових диригентів із навчальної дисципліни «Фортепіано» викладача з багаторічним практичним досвідом у напрямі викладання гри на фортепіано, композитора Руслани Ваврик. Докладно проаналізовано чотири твори для фортепіано: п’єси «Радість» і «Забавка», етюди для розвитку піаністичної техніки № 1 (a-moll) і № 2 (a-moll), a також твір, написаний у жанрі романсу для голосу з фортепіано «Квітка і душа» на вірші поетеси й композитора Мар'яни Лиховид. Дані твори також можуть стати основою для подальшого вивчення та апробації студентами й учнями мистецьких закладів музичного спрямування.

Ключові слова: професійна майстерність майбутніх військових диригентів, удосконалення професійної майстерності, збагачення репертуару, фортепіанні твори.

\section{Enrichment of Piano Repertoire of Future Military Conductors as Improvement of Their Professional Skills}

In the context of improving the professional skills of future military conductors, the teachers of general and specialized musical disciplines of the Department of Musical Art of the National Academy of Land Forces are faced with the task of finding various ways to achieve this goal. One of them is the enrichment of the educational and pedagogical repertory on the discipline «Piano» with the musical works of contemporary authors. The main objective in teaching discipline is to achieve the ability of the cadet to independently perform a musical composition on a highly artistic professional level and skillfully convey its figurative and emotional content to the listener. Increasing the musical performance requirements for future military conductors, short time constraints with the full extent of practical study of musical works according to the working curriculum for the discipline «Piano» requires the teacher to create the appropriate conditions at the lesson to learn the educational material, the introduction of innovations, the application of teaching methods of the subject taking into ac- 
count the musical abilities of each student for the further growth of his/her professional level. While teaching the discipline, the specifics of the educational and pedagogical repertoire of the piano cover such works as sketches, polyphonic works, plays of small forms, works of the great form, ensemble works, accompaniment, etc. The piano repertoire has to cover the most diverse musical works of Ukrainian and foreign composers; it should be characterized by high artistic content, appropriate pedagogical expediency taking into account the general musical development and individual characteristics of each cadet. This publication presents the results of the creative search for the enrichment of the educational and pedagogical piano repertoire of future military conductors from the academic discipline «Piano» of a teacher with many years of practical experience of teaching how to play the piano, a composer - Ruslana Vavryk. Four (4) compositions for the piano are analyzed in detail: the plays «Joy» and «Fun», sketches for the development of piano techniques No. 1 (a-moll) and No. 2 (a-moll), as well as a work written in the genre of the romance for a voice from the piano «Flower and Soul» on the verses of the poet and composer Mariana Likhovid. These works can also be the basis for further study and testing by students of musical artistic institutions.

Key words: professional skills of future military conductors, perfection of professional skill, enrichment of the repertoire, piano works.

Рецензент - кандидат педагогічних наук, старший науковий співробітник С. М. Вдович 